\title{
The Use of Interactive Learning Media for Teachers in Rural
}

\section{Areas}

\author{
Anni Holila Pulungan \\ Faculty of Languages and Arts, Universitas Negeri Medan, Indonesia \\ annholilapulungan@gmail.com
}

\begin{abstract}
Learning media is a tool or means that can facilitate delivery of messages from a learning resource to students. Interactive learning media need to be used by teachers so that the learning process runs well and is attractive to students. Teachers in rural areas still use conventional learning media. They still use simple media made of thick card and simple power point. There is no creation and innovation in it. The research method in this study is descriptive qualitative. Fifteen teachers from the Al Ahliyah Al Islamiyah madrasa, South Tapanuli. They are teachers who teach different subjects, such as Indonesian, Economics, Natural Sciences, Social Sciences, Chemistry, Information Communication Technology, and Mathematics as sources of research data. The purpose of this study was to explain the use of interactive learning media slide master by teachers in rural areas. Data collection techniques using observation, documentation and interviews. The validity of the data used triangulation techniques. Data analysis techniques using techniques of Miles and Huberman. The results obtained from this study indicate that teachers from various different subjects have used interactive learning media properly and correctly. This is based on the achievement of indicators on interactive learning media. And this has an impact on increasing students' learning achievement. And this has an impact on increasing students' learning achievement.
\end{abstract}

Keywords media; interactive learning media; teachers; basic competences; rural areas



\section{Introduction}

A good education requires quality education both in the learning process and in its products. To realize these two elements, a commitment and mutual agreement from educational developers and all levels of society is needed to change. The basic change that must be made is a change in mindset. This is especially true for teachers as educators, as the spearheads of change in the world of education. Teachers must change their teaching patterns, both in their cognitive, attitude and psychomotor way. In relation to the teaching process, teachers must be able to use learning tools effectively and efficiently. Refer to one of the learning tools, namely learning media, many teachers, especially those living in rural areas, have not been able to use interactive learning media in their instructional process effectively. Meanwhile, on the other hand, teachers are required to use technology, especially computers, in learning (Ministerial Regulation Number 74 Concerning Teachers, 2008). With the rapid development of technology, the development of media in learning is also going fast. Learning media is a tool that can help convey messages, 
stimulate creative ideas and the desires of students in the learning process. With the existence of learning media, teaching materials are not clear, it can be clarified through learning media.Various creations and innovations that can be found in learning media. Use of media online creative will enable students to learn better and can improve their performance in accordance with the goals to be achieved (Asnawir, 2002). Learning outcomes are not a mastery of training results, but a change in behavior (Hamalik, 2008: 36).

This is very unfortunate when technological developments are not applied to the learning process in the classroom. It is not easy to use technology in synergy with the media. The interactive learning media analyzed in this study is the master slide media. Based on the results of observations and interviews that have been carried out, data is obtained at the Al Ahliyah Al Islamiyah madrasah that when the teachers explain the lessons many students do not understand the material, are not excited, are bored, do not want to ask questions and are silent. Of course this is not very good for the development of students and their quality in the future. In this study, the use of interactive learning media slide master is applied, how the teachers use it in their teaching and learning process according to the subjects they teach.

\section{Review of Literatures}

\subsection{Learning Concept}

Learning is a process of seeking knowledge and a process of changing behavior. The process of seeking knowledge in learning is part of the learning process, so learning and the learning process cannot be separated, because they are interrelated each other. Yamin (2013) states that learning is the ability to manage components related to learning operationally and efficiently. He also stated that the components related to schools in improving the quality of learning are teachers, students, school supervisors, facilities/infrastructure, and the learning process. From the explanation above, learning and the learning process are the processes of integrating two important components in the behavior change process. As Ningsih, Soetjipto \& Sumarmi (2017) argue that learning activities are very important in the learning process because learning is an activity or process to acquire and strengthen personality.

Learning in the learning process leads to interactions between students and teachers. Dagarin (2004) point out class interaction is "a two-way process between participants in the language process, teachers influence learners and vice versa." This interaction aims to achieve learning objectives. One of the important interactions in class is pedagogic interaction, as Sarosdy et al. (2006) stated that interactions in the classroom are categorized as pedagogic interactions, which means interactions in the teaching and learning process.

Interaction plays an essential part in language classes. First, it can improve students' language knowledge. Rivers (1987) notes that through interaction, students can increase their language retention when they listen to or read authentic linguistic material, or even peer-to-peer students, in discussions, plays, joint problem-solving tasks, or a dialogue journal..." ". Second, strengthen social relationships. Interaction for students will strengthen ties, both between them and with the teacher because it provides opportunities for them to learn from each other and get feedback on their performance (Naimat, 2011). Third, it is useful for developing students' communicative skills. 


\subsection{Instructional Media}

In a learning process, the role of the media is very important to support the achievement of the desired learning goals. Learning media is an integral part of the teaching and learning process in schools. In this era of globalization, teachers in any field of study are required to be able to use and create or design and even develop learning media according to the needs of their students in the classroom. Therefore, teachers must inevitably have sufficient knowledge of instructional media.

Furthermore, learning media is also a learning aid, which is anything that can be used to stimulate thoughts, feelings, attention and abilities or skills of students so that they can encourage the learning process. Thus, it can be said that learning media cannot be separated in teaching and learning activities. The use of learning media is a creative and systematic effort to create experiences that can teach students so that in the end educational institutions will be able to produce quality graduates. Related to this, the media is the speaker's tool to convey his message to the recipient. Heinich (2000) argues that the media is an intermediary or messenger of messages from the sender to the recipient of the message. Learning media is anything that is used to transmit messages and can stimulate thoughts, feelings, concerns and the will to learn so that it can encourage a deliberate, purposeful, controlled learning process (Miarso, 2004). In line with the previous statement, Sardiman (2008) argues that the media is an intermediary or messenger for messages from sender to message recipient. Through the media, students will more quickly understand the material provided, so that learning objectives can be achieved (Rahma, et.al, 2019). In addition, Ray, et.al. (2020) stated that learning media is used to facilitate teachers in delivering subject matter so that students more easily understand the subject matter. It can be argued in this study that the media is a tool that can be used by students to better understand the learning topics given by the teacher over a long period of time.

\subsection{Interactive Learning Media}

In increasingly sophisticated technological developments, teachers are required to be able to use and also develop interactive learning media. It is to make students can easily understand the entire material presented by the teacher. Teachers are required to be able to create and use interactive media in various forms and variations so that they can interact communicatively with students. The understanding of learning media as above is based on the assumption that the education/learning process is identical to a communication process (Prasasti, 2019). Media is used as aids in teaching, where the aids in learning include all tools that can be used to help students learn so that they can make it more effective and efficient (Sitorus, 2019).

Arsyad (2010) says that interactive media is a combination and combination of two or more types of media in the form of text, graphics, animation, sound and images. Sutopo (2003) explains that interactive media is media with users can ask questions and get answers and select program views (display) which will be done next so that the user can program computer to perform the next function in many applications. Meanwhile, Koesnandar (2006) states that interactive multimedia is convergent from various media, such as video, audio, photos, graphics, and text packaged in an integrated and interactive way. It makes multimedia interactive has great potential for use in learning. It can be concluded that interactive learning media is a combination of various types of media such as text, animation, images, sound, video, illustrations in which there are interactive elements so that good communication and interaction between teachers and students is established. 
Moreover, Hamalik (1994) emphasized that a teacher must have sufficient knowledge of teaching media, which includes,
a. Media as a means of communication to make the teaching and learning process more effective;
b. The function of the media in order to achieve educational goals;
c. The input and outcome of the learning process;
d. The relationship between teaching methods and educational media;
e. The value or benefits of educational media in teaching;
f. Selection and use of educational media
g. Various types of educational media tools and techniques;
h. Educational media in every subject;
i. Innovation efforts in educational media.
Thus, the media cannot be separated from the teaching and learning process. In this study using interactive learning media in the form of interactive master slides with the type of presentation in the form of a tutorial model using animation, video, text and the production is assisted by slide master Adobe Flash program. By using this interactive learning media, teachers are expected to see more real or real than just verbal forms in the form of explanatory words given by the teacher or writing in books. The study delivery of subject matter using interactive learning media aids the teacher will require students to be more active in the teaching and learning process.

\section{Research Methods}

The study used descriptive qualitative method. The data sources of the research are teachers from different learning subjects, namely Mathematics, Indonesian, Geography, English, Islamic Religious Education, Natural Sciences, Social Sciences, Economics, and Communication Technology at MA Al Ahliyah Al Islamiyah in South Tapanuli. The data of this study is the use of interactive learning media by teachers with different subjects according to the subjects they teach. Data are analyzed based on data reduction, data presentation, and conclusions drawing.

\section{Discussion}

The study on the use of interactive learning media by teachers with different subjects was conducted at MA Al Ahliyah Al Islamiyah in South Tapanuli. In schools that are far from the city the teachers have used learning media, but these media are still conventional and have not been used properly and effectively. This study examines fifteen teachers from different subjects- Mathematics, Indonesian, Geography, English, Islamic Religious Education, Natural Sciences, Social Sciences, Economics, and Communication Technology, use interactive media effectively and efficiently. Teachers from different subjects have been able to properly and effectively use interactive media in accordance with the subjects they teach. The results of the analysis are described as follows.

a. Indonesian Subjects

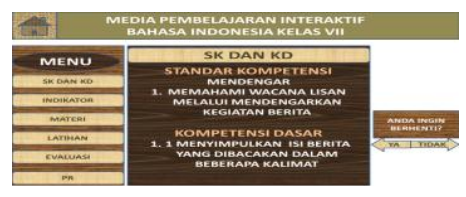

Figure 1. ILM in the Indonesian Subject 
Interactive Learning Media (ILM) in Indonesian subjects designed and used by HRP teachers are very interesting and creative. HRP created the animation "Panda bear moves" to attract students' interest in learning. Furthermore, the use of menus on interactive learning media such as Competency Standards (SK) and Basic Competencies (KD).

In this case this Panda animation can also be made to move. Menus such as competency standards and basic competence, Indicators, Materials, Exercises, Evaluation and Homework can be entered on the master slide. When HRP wants to explain what competency standards and basic competence are, and other learning tools, she just 'clicks' on the function menu that she wanted. After clicking, the required information appears. HRP can also use the stop menu with yes or no answers. If a teacher wants to continue with the explanation of the material then she just clicks the yes button and if not then click the no button.

In addition, the formulation of basic competencies, indicators and learning objectives has been clearly formulated by HRP. The clarity of the formulation and selection of the subject matter is well described so that this will have an impact on students in understanding the material presented. The competency standard to be achieved is understanding oral discourse through listening to news activities. The curriculum used at the AL Ahliyah madrasah is still the KTSP curriculum.

The coloring provided by HRP is also quite good and inconspicuous. The typeface used is also very clear and legible. Overall, the appearance of interactive learning media in the Indonesian field of study is already interesting. By using this learning media attractively, it is hoped that the quality of student learning will increase and in the end students are also interested in wanting to continue learning.

\section{b. Chemical}
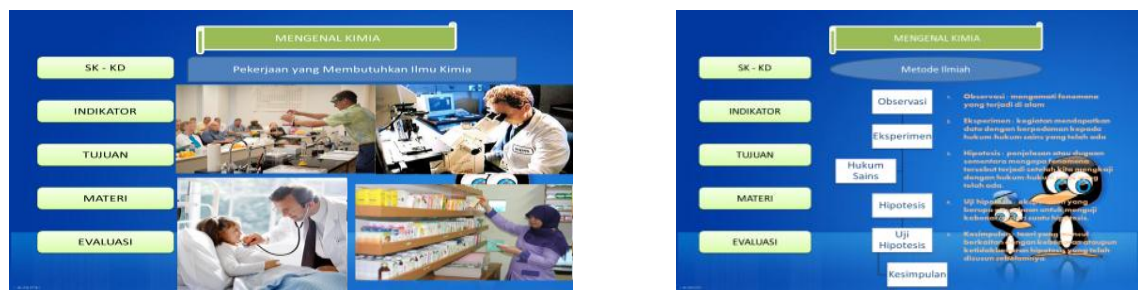

Figure 2. ILM in the Chemical

Meanwhile, IH designed interactive learning media in the field of Chemistry (Figure 2). IH has also been able to use interactive learning media properly and attractively by adding various pictures according to the topic being taught at that time, namely "Getting to know Chemistry", with the competency standard to be achieved is to understand the atomic structure, periodic properties of elements and chemical bonds. IH also added penguin pictures to attract students' interest in learning. IH has been able to use many menus in its interactive learning media, such as observation, experiment, hypothesis, and conclusion menus.

The coloring she uses is also good and bright. Only the use of a typeface that still looks formal. Slide backgrounds use clearly visible colors. Furthermore, the menus displayed on the master slide are also complete according to the needs in Chemistry learning, such as there are indicators and learning objectives, materials and evaluation. By simply clicking on these menus, the learning process will of course run well. Overall, the 
design used by $\mathrm{IH}$ in Chemistry is very good. Of course this has an impact on improving the quality of learning for students.

c. Information and Communication Technology
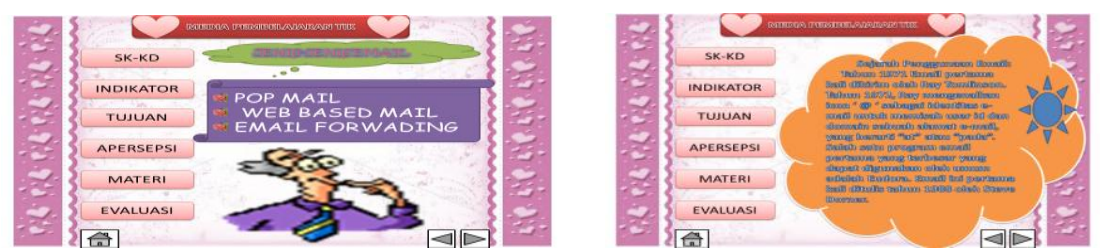

Figure 3. ILM in the Information and Communication Technology

In the subject of information communication and technology, MLH used slide masters very well. He added various pictures that attracted students to see them. There are moving images on the slide as well as shapes with interesting backgrounds. Menus that must be included in the use of interactive media such as basic competencies, learning objectives and indicators, teaching materials and evaluation have also been well completed. The topic of learning is types of email. MLH describes the material types of email in various menus to facilitate teaching. By clicking the evaluation menu, students can immediately find out the questions to be worked on. The coloring he uses also varies greatly. MLH chooses bright colors so that its students can look well. The choice of color in using interactive learning media also affects students' interest in learning.

\section{d. Social Sciences}

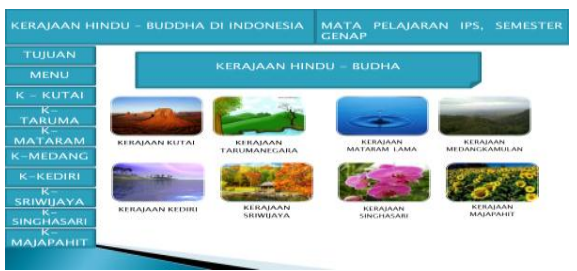

Figure 4. ILM in Social Sciences

Furthermore, the NAP of a teacher in social science subjects used the master slide media very well. On the topic of "Hindu-Buddhist Influence in Indonesia", NAP uses columns that share descriptions of each kingdom, such as Kutai, Tarumanegara, Kediri, Singosari, Majapahit and others. So by clicking on the desired royal column, the information is immediately obtained. The typeface used by NAP is also good as well as the background for clear and attractive coloring. The menus that must be provided also do not forget to use, namely the basic competency menu, learning objectives and teaching and evaluation materials. Teaching materials also provided in the description box.

e. Mathematics

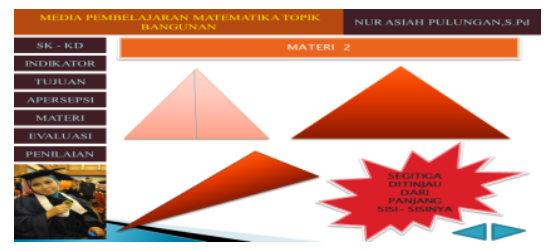

Figure 5. ILM in Mathematics 
In Mathematics, PNA uses various forms of pictures in accordance with the subject topic it teaches, namely "Build Flat". In this topic, PNA uses various triangular shapes. There are forms of isosceles triangles, equilateral triangles, arbitrary triangles and others. In the use of interactive media, the PNA slide master uses red as the main color. This aims to attract students' attention to better understand and follow the learning that is conveyed. PNA also uses a menu of learning indicators and learning objectives. When he explained the lesson, by clicking on the menu, the learning objectives that were expected to be achieved that day were read. Likewise, the teaching material menu is already available in it. This makes it very easy for teachers and will certainly have an impact on the quality of students' mathematics learning.

\section{f. Economics}

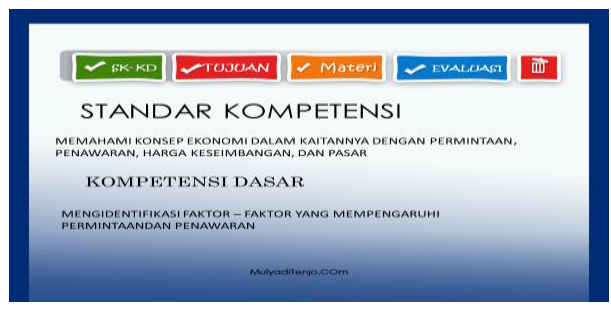

Figure 6. ILM in the Economics subjects

Furthermore, in the subject of Economics, MT uses interactive slide master media well. MT uses and makes menus such as competency standards and basic competencies as well as evaluation. This is a very important element in a teaching and learning process. This is due to the importance of determining what competencies students want to achieve in one subject. The learning objectives delivered by MT in this Economics subject are that students can describe the meaning of demand and supply, students can identify the factors that affect demand, students can identify the factors that affect the supply, and students can draw a demand curve. The colors he uses vary widely for each menu, such as red, green, blue and orange. In determining the coloring of the MT power point master slides it is also good, using bright and clear colors. Of course this is very helpful in the learning process. Furthermore, MT also provides space for evaluation in the form of assignments to students.

\section{g. Geography}
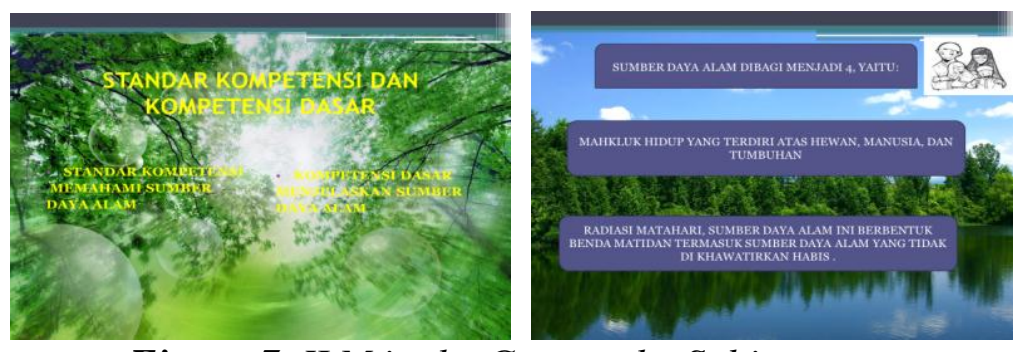

Figure 7. ILM in the Geography Subjects

In the subject Geography, WB used power point very well. He added the background of the media with various pictures that attracted students to see them. Menus that must be included in the use of interactive media such as basic competencies, learning objectives 
and indicators, teaching materials and evaluation have also been well completed. The topic of learning is "Natural Resources". WB describes the material in various menus to facilitate teaching. By clicking the evaluation menu, students can immediately find out the questions to be worked on. The coloring she uses also varies greatly. WB chooses bright colors so that its students can look well. The choice of color in using interactive learning media also affects students' interest in learning.

h. Islamic Education

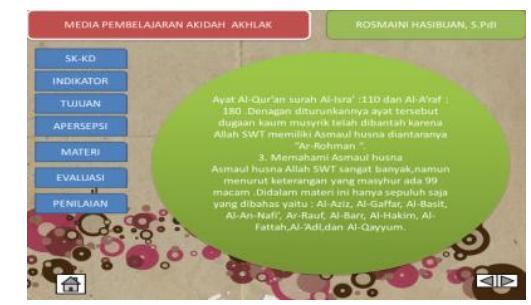

Figure 8. ILM in the Islamic Education subjects

Moreover, RH also makes good use of interactive media. Menus such as competency standards and basic competence, indicators, materials, exercises, evaluation and apperception can be entered on the master slide. When RH wants to explain what competency standards and basic competence are, and other learning tools, she just clicks on the function menu that she wanted. RH can also use the stop menu with yes or no answers. If a teacher wants to continue with the explanation of the material then she just clicks the yes button and if not then click the no button.

In addition, the formulation of basic competencies, indicators and learning objectives has been clearly formulated by RH. The clarity of the formulation and selection of the subject matter is well described so that this will have an impact on students in understanding the material presented. Then, the coloring provided by $\mathrm{RH}$ is also quite good and inconspicuous. The typeface used is also very clear and legible. By using this learning media attractively, it is hoped that the quality of student learning will increase and in the end students are also interested in wanting to continue learning.

\section{Conclusion}

Based on the results of the analysis carried out on teachers at Madrasah Aliyah $\mathrm{Al}$ Ahliyah Al Islamiyah in South Tapanuli, it was concluded that the teachers were able to use interactive learning media very well. They are able to use the menus contained in the learning media. There is a mandatory menu that must be applied in the master slide interactive learning media, namely the basic competency menu, learning indicators and learning objectives. The teachers on the outskirts of the village still use competency standards. They still use the KTSP curriculum. In each menu they are able to fill in the description according to the specified menu. Of course all of this has an impact on improving the quality of student learning. The learning competence of students is increasing.

\section{References}

Asnawir dan M. Basyirudin Usman. (2002). Media Pembelajaran. Jakarta: Ciputat Pers. Azhar A. (2015). Media Pembelajaran. Jakarta: PT Raja Grafindo Persada. 
Dagarin, M. (2004). Classroom Interaction and Communication Strategies in Learning English as a Foreign. Ljubljana: ELOPE.

Hamalik, (1994). Media Pendidikan . Bandung: Citra Aditya Bakti.

Heinich, R. (2000). Instructional Media and New Technology of Instruction. New York: McMillan.

Koesnandar, A. (2006). Pengembangan Software Pembelajaran Multimedia Interaktif. Jurnal Teknodik No. 18/X/Teknodik/Juni/2006. Jakarta: Pustekom.

Miarso, Y. H. (2004). Menyemai Benih Teknologi Pendidikan. Jakarta: Prenoda Media.

Ningsih., Soctjipto, B. E., \& Sumarmi. (2017). Improving the Students' Activity and Learning Outcomes on Social Sciences Subject Using Round Table and Rally Coach of Cooperative Learning Model. Journal of Education and Practice, 8(11), 30-37.

Naimat, G. Kh. (2011). Influence of Teacher Students Interaction on EFL Reading Comprehension. European Journal of Social Sciences Vol. 23 No. 4, pp. 672- 687

Peraturan Pemerintah Republik Indonesia Nomor 74 Tahun 2008 tentang Guru. (Online), (http://www.paudni.kemdikbud.go.id/wpcontent/uploads/2012/08/PPNo74th2008 pdf).(Diakses tanggal 27 September 2012).

Prasasti, T.I., Solin, M., and Hadi, W. (2019). The Effectiveness of Learning Media Folklore Text of North Sumatera Based on Blended Learning by 10th Grade Students of Vocational High SchoolHarapan Mekar-1 Medan. Budapest International Research and Critics in Linguistics and Education (BirLE) Journal Vol 2 (4): 480490.

Rahma, S. et. al. (2019). Packaging Audio Visual Media in Tatak Tintoa Serser in Learning of Dairi Dance. Britain International of Linguistics Arts and Education (BIoLAE) Journal, Vol.1 No.2, pp.153-159.

Ray, S. A. et. al. (2020). The Quality of E-Learning Based on Learning Media Using Moodle LMS on Text of Observation Reports of Grade $10^{\text {th }}$ Students of Vocational School Telkom Shandy Putra Medan Britain International of Linguistics, Arts and Education (BIoLAE) Journal Vol. 2 No. 2, pp. 688-699.

Rivers, W. M. (1987). Interactive Language Teaching. Interaction as the Key to Teaching Language for Communication. New York: Cambridge University Press.

Sardiman, A. M. (2008). Interaksi dan Motivasi Belajar Mengajar. Jakarta: Raja Grafindo Perkasa.

Sitorus, L.S., Mardianto, and Matsum, H. (2020). Development of Powerpoint-Based Learning Media on Learning Aqeedah Morals. Budapest International Research and Critics in Linguistics and Education (BirLE) Journal Vol 3 (2): 958-964.

Sutopo, A. H. (2003). Multi Media Interaktif dengan Flash. Yogyakarta: Graha Ilmu.

Sarosdy, et al. (2006). Applied Linguistics I. Ertekunki az Ember: Unpublished.

Yamin, M. (2013). New Learning Paradigm. Jakarta: Referensi. 